AN ECONOMIC HISTORY

OF MODERN FRANCE,

1730-1914 


\section{An Economic History of Modern France, 1730-1914}

ROGER PRICE

M 
All rights reserved. No part of this publication may be reproduced or transmitted, in any form or by any means, without permission.

First published 1975 in hardback by

Croom Helm Ltd, under the title The Economic Modernisation of France 1730-1880

Revised edition published 1981 in hard cover and paperback by THE MACMILLAN PRESS LTD

London and Basingstoke

Associated companies in Delhi Dublin

Hong Kong Johannesburg Lagos

Melbourne New York Singapore and Tokyo

\section{British Library Cataloguing in Publication Data}

Price, Roger, b. 1944

An economic history of modern France, 1730-1914.

Revised ed.

1. France - Economic conditions

I. Title II. Economic modernisation of

France

$330.9^{\prime} 44$

$\mathrm{HC} 275$

ISBN 978-0-333-29321-8 ISBN 978-1-349-16564-3 (eBook)

DOI $10.1007 / 978-1-349-16564-3$

The paperback edition of this book is sold subject to the condition that it shall not, by way of trade or otherwise, be lent, resold, hired out, or otherwise circulated without the publisher's prior consent, in any form of binding or cover other than that in which it is published and without a similar condition including this condition being imposed on the subsequent purchaser. 


\section{CONTENTS}

Preface

Abbreviations

Introduction

1 COMMUNICATION AND THE DEVELOPMENT OF COMMERCE $c .1730-c .1880$

Roads

Waterways

Railways

Telegraph

20

Commerce

Currency

27

Conclusions

2 AGRICULTURE 42

Part I: Ancien Régime Structure c. 1730-1850 42

Part II: Development within the Structure of the Ancien Régime

61

Part III: Structural Transformation $c .1850-c .1880 \quad 71$

3 INDUSTRIAL DEVELOPMENT $c .1730-c .1880$

Patterns of Change $\quad 93$

$\begin{array}{lr}\text { Building } & 99\end{array}$

$\begin{array}{lr}\text { Textiles } & 101\end{array}$

Metallurgy 109

Power 119

Coal $\quad 120$

Industrial Geography 125

Communication and Market Structures 131

Economic Cycles 137

Capital Investment 142

Financial Institutions 153

The State and the Economy 159

Labour $\quad 168$

4 POPULATION $c .1730-c .1880 \quad 183$

Mortality 184

$\begin{array}{ll}\text { Birth-rate } & 187\end{array}$

Marriage 191

Food supply $\quad 192$ 
Diet 200

Disease 204

Migration 211

5 CRISIS AND CONSOLIDATION OF THE INDUSTRIAL ECONOMY: c. $1880-c .1914$

Agriculture

226

Industry

230

Labour

235

Living Conditions

237

CONCLUSION

242

INDEX

245 


\section{PREFACE}

This book was first published in 1975. The first edition covered the period c. 1730-c. 1880, analysing a long period of gradual economic growth, culminating in a phase of accelerated structural change and the creation of an industrial economy. Certainly by $c .1880$ the contribution to gross national product from industry seems to have exceeded that from agriculture. The subsequent publication by the Presses universitaires de France of two more volumes in the Histoire économique et sociale de la France, Volume 3 covering the period 18151880 , and Volume 4 covering 1880-1914, with a chronological division adopted for much the same reasons as my own, has happily lent support to the original decision concerning the chronological limits to my study.

Paradoxically I have taken the opportunity of another edition to add a chapter covering the period $1880-1914$ in the belief that this will, by completing the survey of the nineteenth century, provide a study of two centuries of economic change in France, which will be of more practical value to students. The period $c .1880-c .1914$ is considered as one of crisis, and recovery from crisis, during which the industrial economy gained in maturity and technical development accelerated, in particular through the introduction of new products especially by the chemical, engineering, electricity and automobile industries; this prepared the way for a 'second industrialisation' in this century.

The First World War provided such a major shock to French society - although surprisingly very little research has been done on these bitter years - that 1914 seems to provide an acceptable point at which to end.

I would like to record my appreciation of the help and advice I have received from my colleagues in the School of Modern Languages and European History of the University of East Anglia, and to the staff of the University Library, and in particular Barry Taylor and Ann Wood. Christopher Johnson of Wayne State University, Detroit, and Charles Tilly of the Centre for Research on Social Organisation of the University of Michigan read the manuscript of the first edition, and my colleagues James Casey and David Barrass have commented on the revisions. I have benefited greatly from the observations they have made. It goes without saying, however, that I bear full responsibility for any errors of judgement or fact. 
I am also very grateful to my publishers, to David Croom and Malcolm Ward of Croom Helm, and to Sarah Mahaffy of Macmillan.

I owe a particular debt of gratitude to Robert and Jane Frugère for their many kindnesses. Above all I want to thank Heather, Richard, Siân and Emily. 


\section{ABBREVIATIONS}

A.B. Annales de Bretagne

A.D.H. Annales de démographie historique

A.E.S.C. Annales (Economies, Sociétés, Civilisations)

A.F. Année Ferroviaire

A.G. Annales de Géographie

A.H.R. American Historical Review

A.H.R.F. Annales historiques de la Révolution française

A.M. Annales du Midi

A.N. Annales de Normandie

B.H.E.S.R.F. Bulletin d'histoire économique et sociale de la révolution française

B.S.H.M. Bulletin de la société d'histoire moderne

C.H. Cahiers d'histoire

C.I.S. Cahiers internationaux de sociologie

C.A. Le Contrat Social

E.A. Economie appliquée

E.C. Etudes et Conjoncture

E.E.R. European Economic Review

E.H.R. Economic History Review

E.S. Economies et sociétés

E.R. Etudes rurales

I.H. Information historique

J.E.B.H. Journal of Economic and Business History

J.E.H. Journal of Economic History

J.I.H. Journal of interdisciplinary History

J.P.N.P. Journal de Psychologie normale et pathologique

M.S. Le mouvement social

P. Population

R.D.M. Revue des deux mondes

R.E. Revue économique

R.F.S.P. Revue française de science politique

R.G.A. Revue de géographie Alpine

R.G.C. Revue générale des chemins de fer et tramways

R.G.L. Revue de géographie de Lyon

R.G.P.S-O Revue géographique des Pyrenées et du sud-ouest

R.H. Revue historique

R.H.E.S. Revue d'histoire économique et sociale

R.H.L. Revue d'histoire de Lyon 
R.H.M.C. Revue d'histoire moderne et contemporaine

R.H.S. Revue d'histoire de la sidérurgie

R.N. Revue du Nord

S.L.G. Société Languedocienne de Géographie

T.A.S. Techniques, arts, sciences 


\section{INTRODUCTION}

The periods into which history has traditionally been divided by historians, solely for their own convenience, have generally been determined by political criteria. Thus 1789 and the Revolution are usually regarded as a major turning point in French history, a place for one book to end and another to begin.

In political and ideological terms the Revolution was no doubt of crucial importance, but humanity was not transformed thereby. Most of the population continued to be subjected to the age-old constraints of their environment. At the end of all the political upheavals of the Revolution and Empire little had changed in the daily life of most Frenchmen.

Continuity deserves a place in history equal with the prominence given to change. The two are inseparable - the one conditioning the other.

This volume is intended to be a study of economic developments in France between $c .1730$ and $c .1914$. The period is conceived as one of growth in production within pre-industrial economic structures, succeeded from 1840-50 by rapid structural transformation and the creation of an industrial economy.

The Ancien Régime économique et sociale was characterised by the predominance of agriculture and of artisanal forms of industrial production, and by technically backward, slow and expensive modes of transport inducing the compartmentalisation of market structures and of human societies. The hallmarks of this kind of society were isolation and localism. The exchange of goods, people and ideas was restricted. The economy was far from stagnant but the volume of trade and, in consequence, the volume and technological development of production, was restrained by the costs of transport. Regardless of the needs of the population the difficulties of distributing the goods produced restricted the potential for development. These basic structures restrained the potential for dynamic action. Changes within them were slow to occur and slow to have extensive effects. It is worth remembering however that if France was underdeveloped in 1850 this was only in relation to Britain, the most economically advanced country in the world, or in relation to her own future development.

If a remarkable event such as the Revolution is placed within such a social context, its human significance can be more accurately assessed. Man does not live by bread alone, and yet until his bread ration is 
assured, its gaining can dominate his existence. In a pre-industrial society sustained interest in politics is the privilege of a small minority. For the vast majority the real revolution must be the one that transforms their material conditions.

Paradoxically this change imprinted itself less forcefully on the human consciousness. Its progress was more gradual and less dramatic, even in the case of major technological innovations like the railway. Yet the social consequences of such changes affected the lives of far more people more profoundly than political revolution in the nineteenth century.

The Revolutions of 1789,1830 , and 1848 occurred within different evolving social situations, characterised by pre-industrial structures. These Revolutions had significant consequences for economic development but contributed far less to its evolution than did the transformation of the structure of the market.

Structural transformation of the market, on a scale sufficient to radically alter the characteristics of demand and the conditions of production occurred with the development of the railway, which was undoubtedly faciliated by prior industrialisation. It however contributed enormously to the acceleration of economic growth, to the establishment of a national market, and of a more national society. This development and its broad consequences was the major revolution in French society in the nineteenth century.

By $c .1880$ the effects of the transport revolution were manifest. Although demographic stagnation, the immobility of rural labour, low productivity in many sectors and the relative slowness of urbanisation restricted changes in the scale and character of the market so that substantial areas of technological archaism survived, society had nevertheless been transformed. If a terminal point has to be assigned to the Ancien Régime, perhaps this could be the period 1850-80 rather than 1789.

Before this time economic structures, material conditions, and even social and political relationships had changed only slowly and to a limited extent. The position adopted here is not that of a transport determinist but rather the view that the transport system was the most important single component in the economic mechanism. By examining the development of communications and its economic consequences it is hoped to validate this assumption. 